\title{
Khana: The blouse material of north Karnataka
}

\author{
PRATIKHYA BADANAYAK AND SADHANA D. KULLOLI
}

Received: 09.03.2017; Revised: 25.04.2017; Accepted: 12.05.2017

See end of the paper for authors' affiliations PRATIKHYA BADANAYAK Department of Textile and Apparel Designing, College of Rural Home Science, University of Agricultural Sciences, DHARWAD (KARNATAKA) INDIA

Email : pratikshyabdnk16@ gmail.com
ABSTRACT : Khana is a unique blouse material produced in Guledgudd that is only one textile cluster of India to make blouse material. Traditional hand woven Khana material is the choli or blouse material with extra warp dobby figuring. This study revealed the details about the unique Khana material of north Karnataka. The primary data were collected through personal interview method from the weavers and secondary data were collected from magazines and from web.

KEY WORDS: Guledgudda, Khana blouse materials

- HOW TO CITE THIS PAPER : Badanayak, Pratikhya and Kulloli, Sadhana D. (2017). Khana: The blouse material of north Karnataka. Asian J. Home Sci., 12 (1) : 208-212, DOI: 10.15740/HAS/AJHS/12.1/ 208-212. 